\title{
Carboniferous-Permian Boundary in Kansas, Midcontinent, U.S.A.
}

\author{
Robert S. Sawin ${ }^{1}$, Ronald R. West ${ }^{2}$, Evan K. Franseen ${ }^{1}$, \\ W. Lynn Watney ${ }^{1}$, and James R. McCauley ${ }^{1}$ \\ ${ }^{1}$ Kansas Geological Survey, 1930 Constant Avenue, Lawrence, Kansas 66047 \\ ${ }^{2}$ Department of Geology, Kansas State University, Manhattan, Kansas 66506
}

\begin{abstract}
The placement of the Carboniferous (Pennsylvanian)-Permian boundary in Kansas has been debated since the rocks of this age were first described and named. With the ratification of the Global Stratotype Section and Point (GSSP) for the base of the Permian System in the southern Ural Mountains, the Carboniferous-Permian boundary in Kansas can now be confidently defined. Based on the identification of the first occurrence of the conodont Streptognathodus isolatus that definitively correlates the Kansas rock section to the basal Permian GSSP, the Carboniferous-Permian boundary in Kansas can be placed at the base of the Bennett Shale Member of the Red Eagle Limestone.

The Kansas Geological Survey proposes that the Tuttle Creek Lake Spillway section, located in northeast Kansas, be considered for the Carboniferous-Permian boundary stratotype in Kansas. It is further suggested that the stratigraphic position of the Carboniferous-Permian boundary in the Tuttle Creek Lake Spillway section be considered as a potential North American stratotype.

In addition to being a significant biostratigraphic boundary, the Carboniferous-Permian boundary and enclosing strata also have significance because they reflect important geologic events and changes that occurred on a regional and global scale.
\end{abstract}

\section{Introduction}

The placement of the Carboniferous (Pennsylvanian)Permian boundary in Kansas, and in all of North America, has been debated since the rocks of this age were first described and named in the midcontinent. In Kansas, at least 84 references have expressed an opinion as to where the boundary should be placed (e.g. Moore, 1940; Moore, 1949; Mudge and Yochelson, 1962; Baars, Ritter, et al., 1994). Until recently, the fundamental problem of defining the boundary has been the inability to confidently tie the North American section to the type Carboniferous-Permian in Eurasia, primarily because the type area was never clearly defined (Mudge and Yochelson, 1962; Baars, 1990). Many correlations were based on fusulinids, including the latest proposed revision in Kansas (Baars, Ross, et al., 1994). With the ratification of the Global Stratotype Section and Point (GSSP) for the base of the Permian System in the southern Ural Mountains by the International Union of Geological Sciences (IUGS) (Davydov et al., 1998), the Carboniferous-Permian boundary in Kansas can now be confidently defined. Based on new conodont data that definitively correlate the Kansas rock section to the basal Permian GSSP, the Carboniferous-Permian boundary in Kansas can be placed at the base of the Bennett Shale Member of the Red Eagle Limestone (fig. 1).

\section{Historical Boundary Placement}

The occurrence of Permian rocks in Kansas, based on fossils collected by Major Frederick Hawn, was first announced by Swallow (1858a, 1858b). Early studies recognized the difficulty of defining the Carboniferous-Permian boundary in Kansas because the rocks seemed to contain a mixed assemblage of Carboniferous and Permian marine fossils, and a clear stratigraphic unconformity or lithologic change was not recognized. Several boundaries, ranging from the Fort Riley limestone (Chase Group) down to the Americus limestone (Council Grove Group) (current terminology), were advanced (see Moore, 1940, 1949). Moore and Moss (1934) reported what they believed to be a major disconformity, traceable from Nebraska to Oklahoma, above the Brownville Limestone Member of the Wood Siding Formation. By 1940, the top of the Brownville limestone, although generally recognized as somewhat arbitrary, had become the accepted boundary between the Carboniferous and Permian in Kansas. Mudge and Yochelson (1962) studied the stratigraphy and paleontology of the uppermost Carboniferous (Pennsylvanian) and lowermost Permian rocks in Kansas and found no evidence for placing the systemic boundary at the top of the Brownville limestone, but suggested leaving the boundary there because it had become firmly entrenched in the literature. The latest accepted stratigraphic guide and chart for Kansas (Zeller, 1968) retained this boundary placement. The boundary remained at the top of the Brownville limestone until Baars, Ross, et al. (1994) proposed moving it upsection to the base of the Neva limestone, a member of the Grenola Limestone. Baars, Ritter, et al. (1994) then elevated the Neva limestone to formation status. 
Carboniferous-Permian Boundary in Kansas, Midcontinent, U.S.A. 2

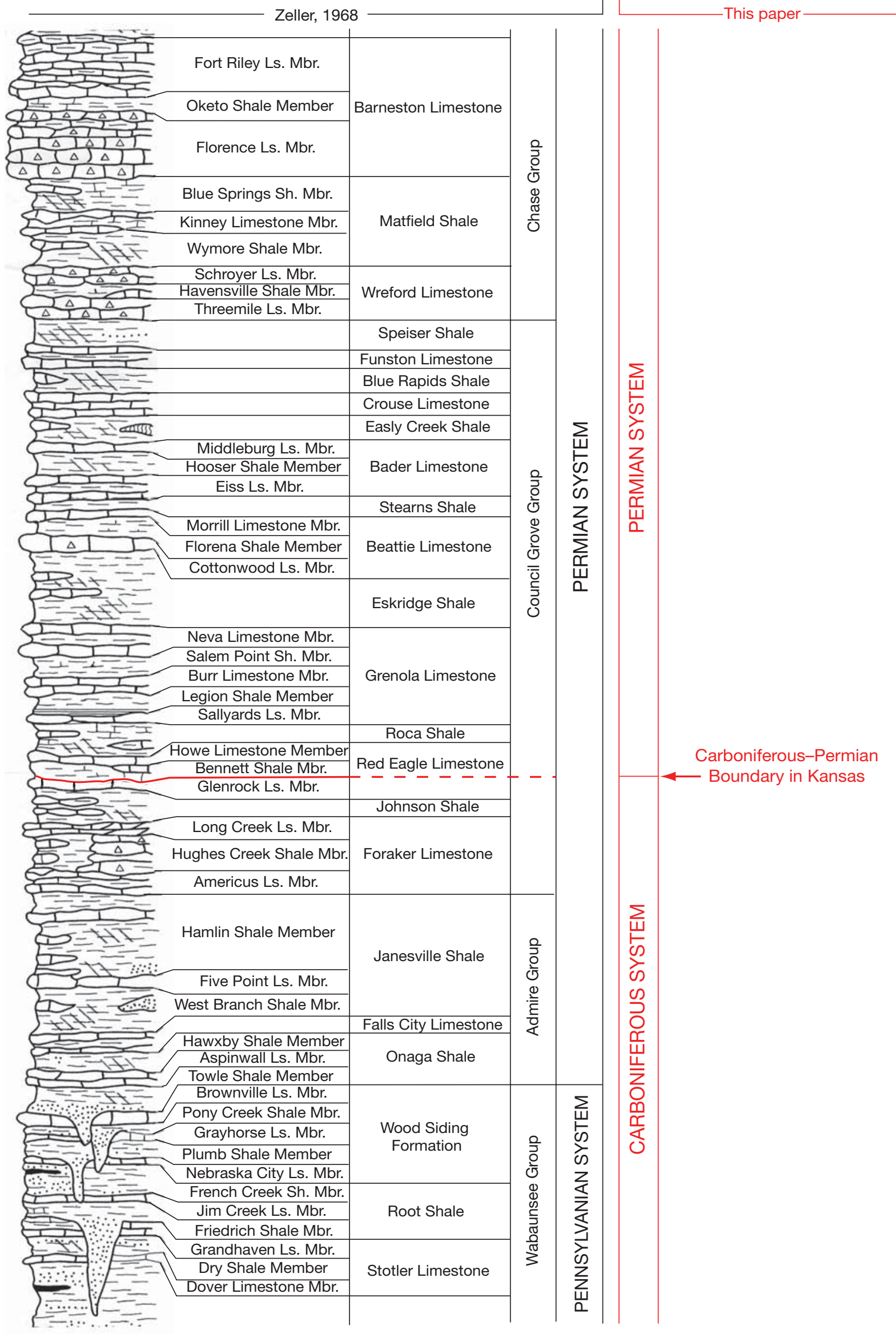

FIGURE 1-Placement of the Carboniferous (Pennsylvanian)-Permian boundary in the latest accepted stratigraphic guide and chart for Kansas (modified from Zeller, 1968) compared to the placement described in this report. 


\section{Carboniferous-Permian Biostratigraphy}

Historically, ammonoids and fusulinids have been the primary index fossils used to establish a biostratigraphic framework for the Carboniferous and Permian. Ammonoid cephalopods have been considered useful because of their relatively rapid rate of evolution, readily recognizable morphological changes, and their pelagic/nektonic mode of life, which resulted in their wide geographic distribution. However, ammonoid fossils are only locally abundant in CarboniferousPermian strata, and recent studies (Boardman et al., 1994) suggest longer periods of morphological stability than previously thought.

Because of their small size, abundance, rapid evolutionary rate, and readily recognizable morphological differences, fusulinids also are useful in establishing a biostratigraphic framework, particularly in the subsurface. However, their benthic lifestyle and general habitation of shallow normal marine paleoenvironments limits their distribution; thus, they can be absent from critical stratigraphic intervals in the diverse cyclic stratigraphic sections in the Carboniferous and Permian of Kansas.
Spores and pollen have potential for wide geographic dispersal but are not sufficiently diagnostic to permit identification of the Carboniferous-Permian boundary.

Conodonts, an apatitic tooth-like microfossil that are internal structures of pelagic animals, are widely distributed both in space and time, and have become the most widely used index fossils in Paleozoic marine strata. Sweet (1988, p. 149) stated "conodont species may be collected from sedimentary rocks that represent a wide variety of depositional environments. In addition, many conodont species have been shown to have had a very broad geographic distribution, and a few may have been cosmopolitan. Those facts, together with the elongate, worm-like body and distinctively finned tail of the few complete specimens known, support the generally held conclusion that the animals were probably nektonic in habit and that distribution of most species may have been largely independent of conditions on the bottom." Conodonts have become the best biostratigraphic tool for studies of the Carboniferous-Permian sequences because they are abundant and widely distributed, and they evolved rapidly over short periods of geologic time.

\section{The Eurasian Carboniferous-Permian Boundary Stratotype}

The GSSP for the base of the Permian System (and base of the Asselian Stage) is located at Aidaralash Creek, Aktöbe region, southern Ural Mountains, northern Kazakhstan (Davydov et al., 1998). The boundary interval occurs within a mudstone-siltstonefine sandstone lithofacies that is completely within a maximum flooding unit free of disconformities (Wardlaw, Davydov, et al., 2004).

The GSSP is defined by the first occurrence of the conodont Streptognathodus isolatus, which developed from an advanced morphotype in the $S$. wabaunsensis chronocline (Chernykh et al., 1997). The first occurrences of Streptognathodus invaginatus and $S$. nodulinearis, also morphotypes of $S$. wabaunsensis, nearly coincide with the first occurrence of $S$. isolatus and can be used as accessory indicators for the boundary (Davydov et al., 1998).

The Carboniferous-Permian GSSP closely approximates the traditional boundaries that were defined by ammonoid cephalopods and fusulinacean foraminifers. The traditional ammonoid boundary is $26.8 \mathrm{~m}(88 \mathrm{ft})$ above the GSSP and is represented by the termination of the Prouddenites-Uddenites lineage and the introduction of the Permian taxa Svetlanoceras primore and Prostacheoceras principale (Davydov et al., 1998). Using ammonoids to identify the Carboniferous-Permian boundary at the GSSP is problematic because 1) ammonoids of critical stratigraphic significance are rare, 2) an interval of 27.5 $\mathrm{m}(90 \mathrm{ft})$ exists between the last documented Carboniferous ammonoid and the first Permian occurrence, and 3) most ammonoid species from the Ural Mountains appear to be endemic (Davydov et al., 1998).
The traditional fusulinid boundary is $6.3 \mathrm{~m}(21 \mathrm{ft})$ above the GSSP and is defined at the first occurrence of the inflated schwagerinids of the Sphaeroschwagerina vulgaris aktjubensisS. fusiformis Zone (Davydov et al., 1998). Davydov et al. (1998) listed three reasons why fusulinids present a significant problem in defining the Carboniferous-Permian boundary: 1) fusulinids were benthic organisms making their distribution somewhat provincial, 2) most were confined to shallow-water carbonate facies, but may have been redeposited in deeper water facies or reworked from older deposits, and 3) taxonomy is in a state of flux and regional interpretations vary substantially.

The palynology of the Carboniferous-Permian boundary stratotype at Aidaralash Creek in Kazakhstan has been investigated by Dunn (2001). He examined palynological residues from 16 samples from a 50-m (164-ft) interval-from $24.2 \mathrm{~m}(79 \mathrm{ft})$ below to $26 \mathrm{~m}(85 \mathrm{ft})$ above the boundary. His results indicate that this interval is similar to that referred to as the Limitisporites monstruosus - Vittatina costabilis assemblage zone reported by Utting (1989) from the Artinskian of the Sverdrup basin in the Canadian Arctic. Dunn also documented a decrease in the relative abundance of palynomorphs across the conodont-defined Carboniferous-Permian boundary, with only two of the 22 palynomorph taxa identified as being exclusively Gzhelian (uppermost Carboniferous) and only one exclusively Asselian (lowermost Permian). The two exclusively Gzhelian taxa occur $5.1 \mathrm{~m}(17 \mathrm{ft})$ and $7.1 \mathrm{~m}(23 \mathrm{ft})$ below the boundary and the one Asselian taxon occurs $7.4 \mathrm{~m}(24 \mathrm{ft})$ above the boundary (Dunn, 2001, fig. 4). 


\section{Biostratigraphic Characteristics of the Carboniferous-Permian Boundary in Kansas}

\section{Conodonts}

Conodonts have emerged as the predominant biostratigraphic fossil group used to define the Carboniferous-Permian boundary. The conodont succession at the Permian GSSP occurs in several other sections in the southern Ural Mountains, the midcontinent of the U.S.A. (Ritter, 1995, Boardman et al., 1998), in West Texas (Wardlaw and Davydov, 2000), and in China (Wang, 2000), as well as in many other intervening localities (Wardlaw, Davydov, et al., 2004).

In Kansas, the Carboniferous-Permian boundary, based on the first occurrence of the conodont Streptognathodus isolatus, is at the base of the Bennett Shale Member of the Red Eagle Limestone (Boardman et al., 1998; Wardlaw and Davydov, 2000; Sanderson et al., 2001; Wahlman and King, 2002; Olszewski and Patzkowski, 2003; Wardlaw, Boardman, et al., 2004). In most places the Bennett Shale Member is underlain by the Glenrock Limestone Member of the Red Eagle Limestone.

\section{Fusulinids}

Thompson (1954) described the fusulinids from the Carboniferous-Permian boundary interval in Kansas (i.e., Admire, Council Grove, and Chase Groups). Subsequently, Douglass (1962), Baars, Ross, et al. (1994), Wahlman (1998, in press), Sanderson et al. (2001), and Wahlman and King (2002) discussed the fusulinid biostratigraphy of the boundary interval.

Baars, Ross, et al. (1994) used the first occurrence of the inflated fusulinid Paraschwagerina kansasensis to define the base of the Permian at the base of the Neva Limestone Member of the Grenola Limestone. However, in discussing the conodont work that was rapidly progressing at the time Baars, Ross, et al., 1994 (p. 7) recognized that "correlations are not yet firmly established in the Southern Ural Mountains of Russia and Kazakhstan" and "If an ammonoid or some other conodont zonation were to be employed in defining the basal Permian in the type area, the Pennsylvanian-Permian boundary may move eventually somewhat below the Neva Limestone Member."

Since the conodont-based assignment of the CarboniferousPermian boundary, Wahlman (1998, in press), Sanderson et al. (2001), and Wahlman and King (2002) have discussed the fusulinid biostratigraphy of the boundary interval. The fusulinid assemblage in the Glenrock limestone, the rock unit immediately below the boundary, contains Triticites rockensis, Leptotriticites glenensis, and Schwagerina campa (Thompson, 1954). The first (i.e., next youngest) fusulinid assemblage above the Carboniferous-Permian boundary that has been described in Kansas is from the Neva limestone, approximately 14 m (46 ft) (Olszewski, 2000) above the Glenrock limestone. The Neva limestone fusulinid assemblage includes Paraschwagerina kansasensis, Schwagerina longissimoidea, and the three largest species of Leptotriticites (L. koschmanni, L. tumida, and L. obesa) (Thompson, 1954). The next higher fusulinid assemblages above the Neva limestone are from the Beattie Limestone (Cottonwood and Morrill Limestone Members) and include Schwagerina jewetti, S. emaciata, S. vervillei, Schubertella kingi, and Triticites sp. (Thompson, 1954).
Thus, fusulinids are transitional across the CarboniferousPermian boundary in Kansas and are not accurate indicators of the boundary. However, several new species appear above the boundary and clearly define the earliest Permian (Nealian substage of the Wolfcampian Stage) in Kansas (G. P. Wahlman, personal communication, February 2006).

\section{Ammonoids}

The most recent data on ammonoid assemblages from the upper Paleozoic in Kansas are contained in Boardman et al. (1994), who pointed out that ammonoids from the uppermost Virgilian and lowermost Permian in the northern midcontinent are poorly known (Boardman et al., 1994, p. 28). Ammonoid genera considered as zonal indices for the Virgilian and Asselian (Wolfcampian) stages are Shumardites and Svetlanoceras, respectively, but the former extends into the Asselian and the latter occurs only in the upper Asselian (Boardman et al., 1994, fig. 16). Other ammonoid genera that occur in the midcontinent are Kargalites, Daixites, Artinskia, Almites, Subperrinites, and Mescalites (Boardman et al., 1994, fig. 16). Mescalites discoidale and Eoasianites cf. E. subtilicostatus are both reported from the lowest limestone in the Hughes Creek Shale Member of the Foraker Limestone and from the upper part of the Bennett Shale Member of the Red Eagle Limestone in the northern midcontinent (Boardman et al., 1994, fig. 7). Prothalassoceras sp. also occurs in the lowest limestone in the Hughes Creek Shale Member and Subperrinites bakeri is reported from the Neva Limestone Member of the Grenola Limestone (Boardman et al., 1994, fig. 7). Subperrinites is a Permian genus, but Prothalassoceras extends into the Asselian from the Virgilian (Boardman et al., 1994, fig. 16). Ammonoids have not been reported from the interval between the base of the Howe Limestone Member of the Red Eagle Limestone and the top of the Salem Point Shale Member of the Grenola Limestone. Therefore, although ammonoids from Kansas exposures are indicators of the general Carboniferous-Permian boundary interval, they are not accurate indicators of the boundary horizon.

\section{Palynology}

Barker (1983) and Barker and Eames (1988) studied palynomorphs from the Admire through Chase Groups (Permian) in Kansas. Ninety-four samples from a continuous core, the Amoco No. 1 Hargrave, were examined (Barker and Eames, 1988) (they did not examine samples from the Red Eagle Limestone and Roca Shale). Barker (1983) stated (p. 231) "the Admire assemblage is qualitatively transitional at the generic level and possesses miospore genera representative of the Upper Pennsylvanian through the Permian (Leonard); the limited occurrence of striate pollen in the Admire Group does not substantiate a Permian age; palynologically, a horizon somewhere between the Admire Group and the El Reno Group (of western Oklahoma) would be more appropriate." Barker (1983), Barker and Eames (1988), and Dunn (2001) recognized some of the same genera, but a meaningful comparison of these earlier data 
with those of Dunn (2001) would require an evaluation of the earlier taxonomy relative to that used by Dunn (2001). Such a re-evaluation might result in the recognition of the Limitisporites
monstruosus-Vittatina costabilis assemblage zone as noted by Dunn (2001). At present, palynomorphs are not useful indicators of the Carboniferous-Permian boundary in Kansas.

\section{Carboniferous-Permian Boundary Stratotype in Kansas}

The Kansas Geological Survey proposes that the Tuttle Creek Lake Spillway section, located in northeast Kansas, be considered for the Carboniferous-Permian boundary stratotype in Kansas. It is further suggested that the stratigraphic position of the Carboniferous-Permian boundary in the Tuttle Creek Lake Spillway section be considered as a potential North American stratotype.

The Tuttle Creek Lake Spillway section is located in Pottawatomie County approximately $5 \mathrm{mi}(8 \mathrm{~km})$ north of Manhattan, Kansas (fig. 2). The spillway is at the east end of the dam. In 1993, heavy rains created record water levels in the lake. Water was released through the spillway flood gates, resulting in extensive erosion of the spillway area below the spillway apron. Over 100 vertical feet $(30 \mathrm{~m})$ of Carboniferous and Permian rocks were exposed as bedding plane surfaces covering several thousand square feet. Weathering and vegetation have somewhat diminished the spectacular nature of the exposures uncovered by the flood, but the spillway area remains an excellent locality to observe the Red Eagle Limestone (fig. 3) and should remain so in the foreseeable future. The spillway is on public property (U.S. Army Corps of Engineers) and is readily accessible.

The Tuttle Creek Lake Spillway section has been extensively studied; several measured sections are available (Miller, 1994; West, 1994; Keairns, 1995; Olszewski, 2000), and numerous publications cite this locality, including several specific to the Carboniferous-Permian boundary (Ritter, 1995; Boardman et al., 1998; Olszewski and Patzkowsky, 2003; Wardlaw, Davydov, et al., 2004; Wardlaw, Boardman, et al., 2004).

All three members of the Red Eagle Limestone-the Glenrock limestone, Bennett shale, and Howe limestone (in ascending order)-are present and readily distinguishable at the Tuttle Creek Lake Spillway section. The lower and upper Red Eagle Limestone contacts with the Johnson Shale and Roca Shale, respectively, are sharp, and paleosols within the Johnson and Roca here have been documented and studied (Miller et al., 1996; Miller and West, 1998; Olszewski and Patzkowsky, 2003).

\section{Glenrock Limestone Member $(0.7 \mathrm{~m} / 2.3 \mathrm{ft})$}

The bottom $2.5 \mathrm{~cm}$ ( 1 inch) of the Glenrock is a brecciated carbonate mudstone. Most of the Glenrock is a light-gray, intraclastic packstone/grainstone that is sparsely fossiliferous except for the upper 2-3 cm (0.8-1.2 inches), which is a highly fossiliferous packstone/wackestone dominated by fusulinids. The upper surface contains borings and/or burrows filled with black shale from the overlying Bennett Shale Member (Miller, 1994; West, 1994). The basal Bennett shale represents a major flooding event with a possible hardground at the top of the Glenrock limestone (Boardman et al., 1998). Boardman et al. (1998, p. 23) reported Streptognathodus conodonts in the uppermost part of the Glenrock, but it was "unclear as to whether they are from the Glenrock limestone or from the Bennett shale inclusions in the burrow systems." Earlier works (Chernykh and Ritter, 1994; Davydov et al., 1995; Ritter, 1995; Chernykh and Ritter, 1997; Davydov et al., 1998) placed the first occurrence of the “isolated-nodular" form of Streptognathodus (S. isolatus) in the Glenrock limestone, but publications after Boardman et al. (1998) (Wardlaw and Davydov, 2000; Sanderson et al., 2001; Olszewski and Patzkowski, 2003; Wardlaw, Boardman, et al., 2004) place the first appearance of $S$. isolatus at the base of the Bennett shale.

\section{Bennett Shale Member $(1.1 \mathrm{~m} / 3.7 \mathrm{ft})$}

The Bennett is a black fissile shale that contains orbiculoid brachiopods, fish teeth and bones, and Streptognathodus conodonts (Boardman et al., 1998). The upper $15 \mathrm{~cm}$ (6 inches) contains burrows filled with skeletal debris. The base of the Bennett is a marine condensed section based on the significant increase in the number of conodonts in this interval (Boardman et al., 1998). The first appearance of Streptognathodus isolatus has been identified at the base of the Bennett shale at the Tuttle Creek Spillway section (Boardman et al., 1998; Wardlaw, Boardman, et al., 2004).

\section{Howe Limestone Member $(1.2 \mathrm{~m} / 4.0 \mathrm{ft})$}

The Howe is a yellowish-gray fossiliferous wackestone/ packstone/grainstone. Fusulinids are most conspicuous in the middle part of the limestone, but the Howe fusulinids have not been described. The top is capped by a skeletal grainstone and columnar stromatolites. 

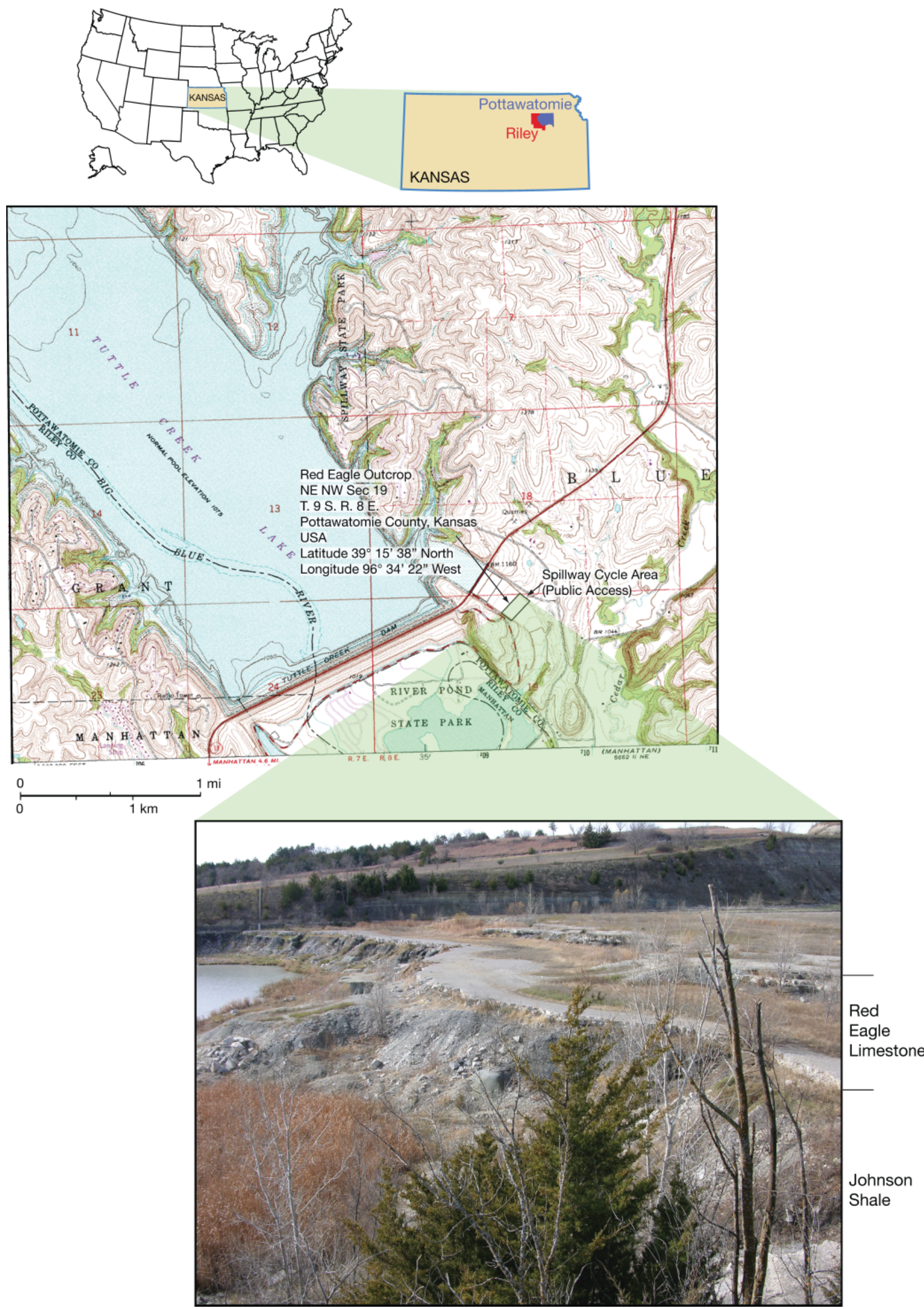

FIGURE 2-Portion of the 7 1/2-minute Tuttle Creek Dam quadrangle (Kansas) showing the location of the Tuttle Creek Lake Spillway section of the Red Eagle Limestone. Photograph (looking west) shows the uppermost Johnson Shale and Red Eagle Limestone outcrop at the spillway. 


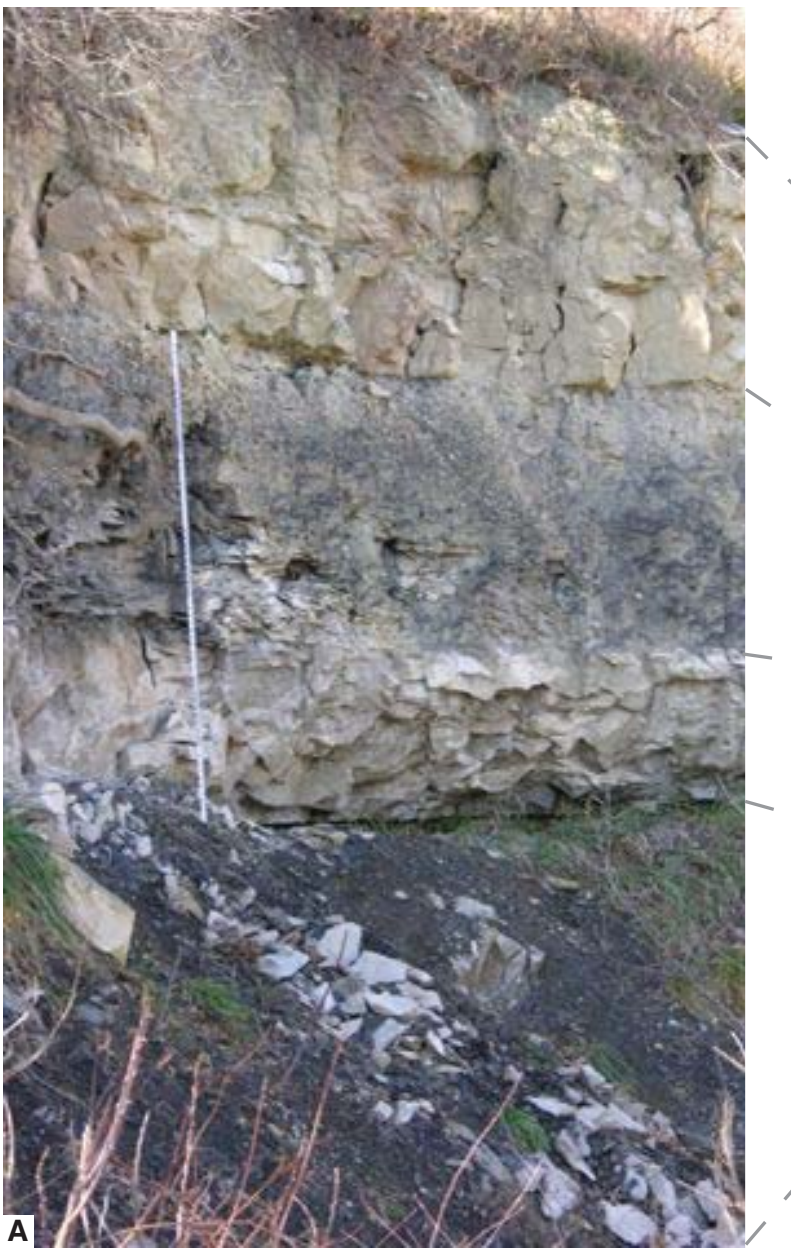

FIGURE 3-Stratigraphic section (modified from Miller, 1994) and outcrop photographs from the Tuttle Creek Lake Spillway. A) Photograph showing representative outcrop expression of the upper portion of the Johnson Shale, Glenrock limestone, Bennett shale, and Howe limestone. Measuring tape is $6.5 \mathrm{ft}(2 \mathrm{~m})$ in length. B) Photograph of the uppermost Johnson Shale and Glenrock limestone. Note sharp contact at the base of the Glenrock limestone. Measuring tape is $4 \mathrm{ft}(1.2 \mathrm{~m})$ in length. C) Photograph of the uppermost Johnson Shale, Glenrock limestone, and Bennett shale. Rock hammer is placed at the contact between the Glenrock limestone and Bennett shale, representing the CarboniferousPermian boundary. The upper Glenrock limestone surface is sharp, irregular (cm-scale relief), and locally shows burrowing and fractures that are filled in with overlying Bennett shale at this locality. the calcareous-rich facies at the top of the Bennett shale (arrow) and a sharp contact with the overlying Howe limestone. Measuring tape is 5 $\mathrm{ft}(1.5 \mathrm{~m})$ in length. E) Photograph of uppermost portion of the Howe limestone. Locally exposed stromatolites cap the Howe limestone at this locality. Scale in photos is in centimeters and inches. 


\section{Correlations and Regional Extent}

Heald (1916) named the Red Eagle Limestone and designated exposures southwest of Foraker, Osage County, Oklahoma, as the type locality. Unable to locate Heald's original section, Keairns and Boardman (2001) proposed a new principal reference section for the Red Eagle Limestone near Burbank, Osage County, Oklahoma; however, they did not differentiate the members. Condra (1927) named the type localities for the Glenrock Limestone, Bennett Shale, and Howe Limestone Members from exposures in southeast Nebraska.

Outcrops of the Red Eagle Limestone can be traced from southeast Nebraska to north-central Oklahoma (O'Connor and Jewett, 1952; Mudge and Yochelson, 1962; McCrone, 1963) (fig. 4). The Red Eagle pinches out in central Oklahoma (Lincoln County) where a facies change to siliciclastic red beds occurs (Branson, 1964). From outcrop exposures, the Red Eagle dips gently westward into the subsurface where it loses its identity in eastern Colorado in siliciclastic deposits of the Fountain Formation (O'Connor and Jewett, 1952). The thickness of the Red Eagle in Kansas ranges from approximately 10 to $35 \mathrm{ft}$ (3$10.7 \mathrm{~m}$ ) (O’Connor and Jewett, 1952).

From southwest Greenwood County, Kansas, northward into Nebraska, the Red Eagle Formation is characteristically limestone and gray to black shale in about equal proportions ( $\mathrm{O}^{\prime}$ Connor and Jewett, 1952). In southern Kansas and north-central Oklahoma, the Bennett Shale Member changes from shale to predominately limestone. In the limestone facies, shale occurs in one or two thin beds at the base of the interval and as thin partings in the middle or upper part (O'Connor and Jewett, 1952). The basal shales and lower foot or less of limestone in the Bennett shale contain the Orbiculoidea assemblage that is characteristic of this interval. This Orbiculoidea zone is at the base of the Bennett shale and can be traced from Oklahoma to Nebraska (O'Connor and Jewett, 1952).

A cored gas well from the Panoma Gas Area, the Amoco Luke Gas Unit \#4 (sec. 8, T. 30 S., R. 39 W.) in extreme western Kansas (Stanton County) (see electric log and core images of the Red Eagle interval between 2,864-2,894 ft at http://abyss. kgs.ku.edu/pls/abyss/qualified.well page.DisplayWell?f $\underline{\text { kid}=1006155585}$ ) demonstrates how different the Red Eagle Limestone is in this area relative to the sequence in the eastern part of the state. At this western location, the Howe Limestone Member is silty, and the dark-gray, radioactive Bennett shale is a distinct marker underlain by siliciclastics of the Johnson Shale. The Glenrock limestone is absent in this core.

In Kansas, the lithologies of the three Red Eagle members are distinct (except in the subsurface of extreme western Kansas as noted above) and can even be distinguished in the southern part of the outcrop belt where the formation is almost entirely limestone (O'Connor and Jewett, 1952).

\section{Depositional History}

The strata that bracket the Carboniferous-Permian boundary record sedimentation on a broad shallow marine shelf that sloped southward toward the Anadarko basin. The midcontinent epeiric sea had a limited connection to the open ocean to the southwest between the Amarillo-Wichita and Sierra Grande uplifts (McKee and Oriel, 1967; Hoy and Ridgeway, 2003). According to paleogeographic reconstructions (Scotese and McKerrow, 1990; Scotese, 2004; Blakey, 2005), the midcontinent was located in tropical to subtropical latitudes north of the equator and gradually migrated northward throughout Permian time. The narrow $(\sim 100-\mathrm{km} / 62-\mathrm{mi})$ passage between the Amarillo-Wichita and the Sierra Grande uplifts shallowed from a basinal to restricted shelf environment between the Late Carboniferous and Early Permian (Dutton and Goldstein, 1988) during a declining migrating deformation of the foreland (Dorobek, 2004) as the MarathonOuachita thrust belt migrated southward into Texas (Dickinson and Lawton, 2003). Increasing restriction and shallowing of the passage due to tectonism and a trend of increasing aridity during the Wolfcampian contributed to the increasing presence of episodic evaporite accumulation during regressions. The seaway eventually became more shallow and restricted, resulting in the abrupt onset of extensive subaqueous evaporite accumulation during the Leonardian (Watney et al., 1988).

Wolfcampian (lowermost Permian) strata are cyclic in character and, like upper Carboniferous (Pennsylvanian) cyclothems, probably record glacio-eustatic fluctuations in sea level as well as paleoclimatic and tectonic influences (e.g., West et al., 1997). Although interpretations of exact depositional environments and water depths have varied somewhat between

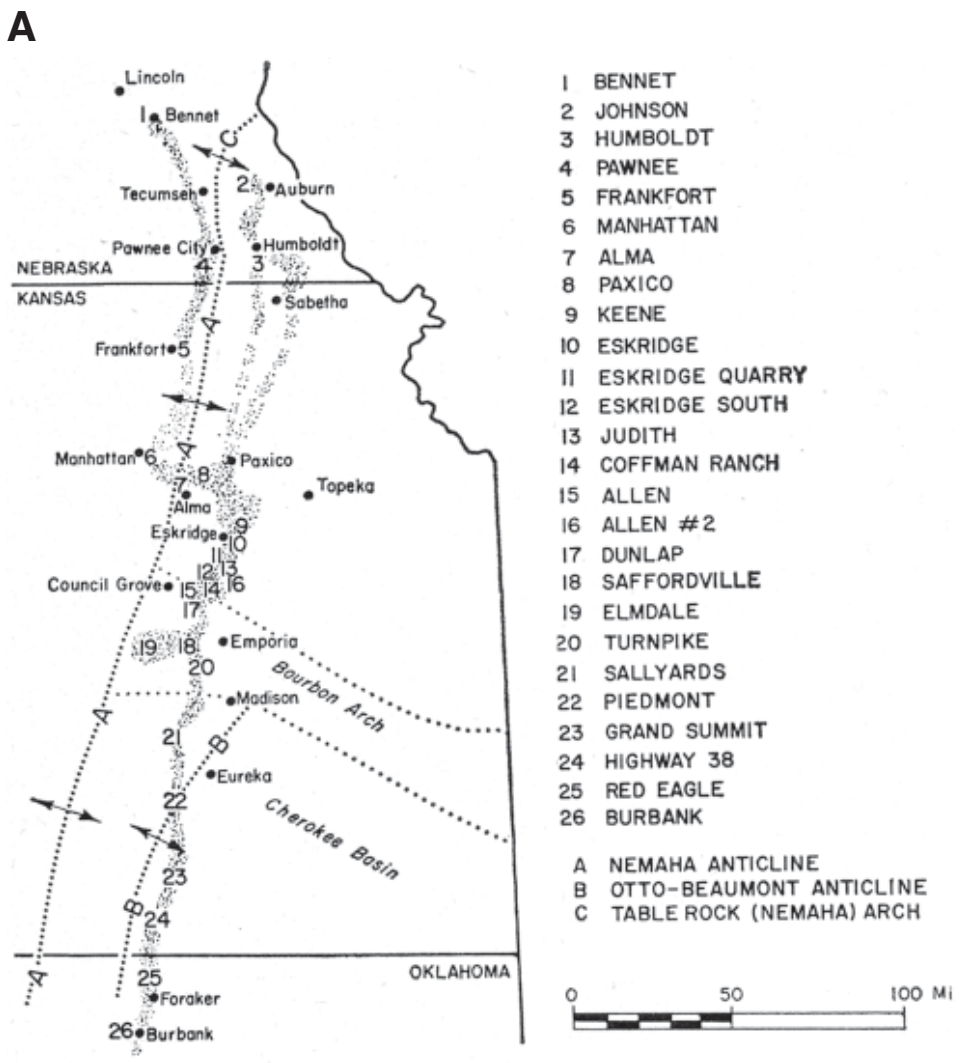

FIGURE 4-A) Location of cross section and B) cross section showing Red Eagle Limestone correlations from Bennett, Nebraska, to Burbank, Oklahoma (modified from McCrone, 1963). 
Carboniferous-Permian Boundary in Kansas, Midcontinent, U.S.A. 9

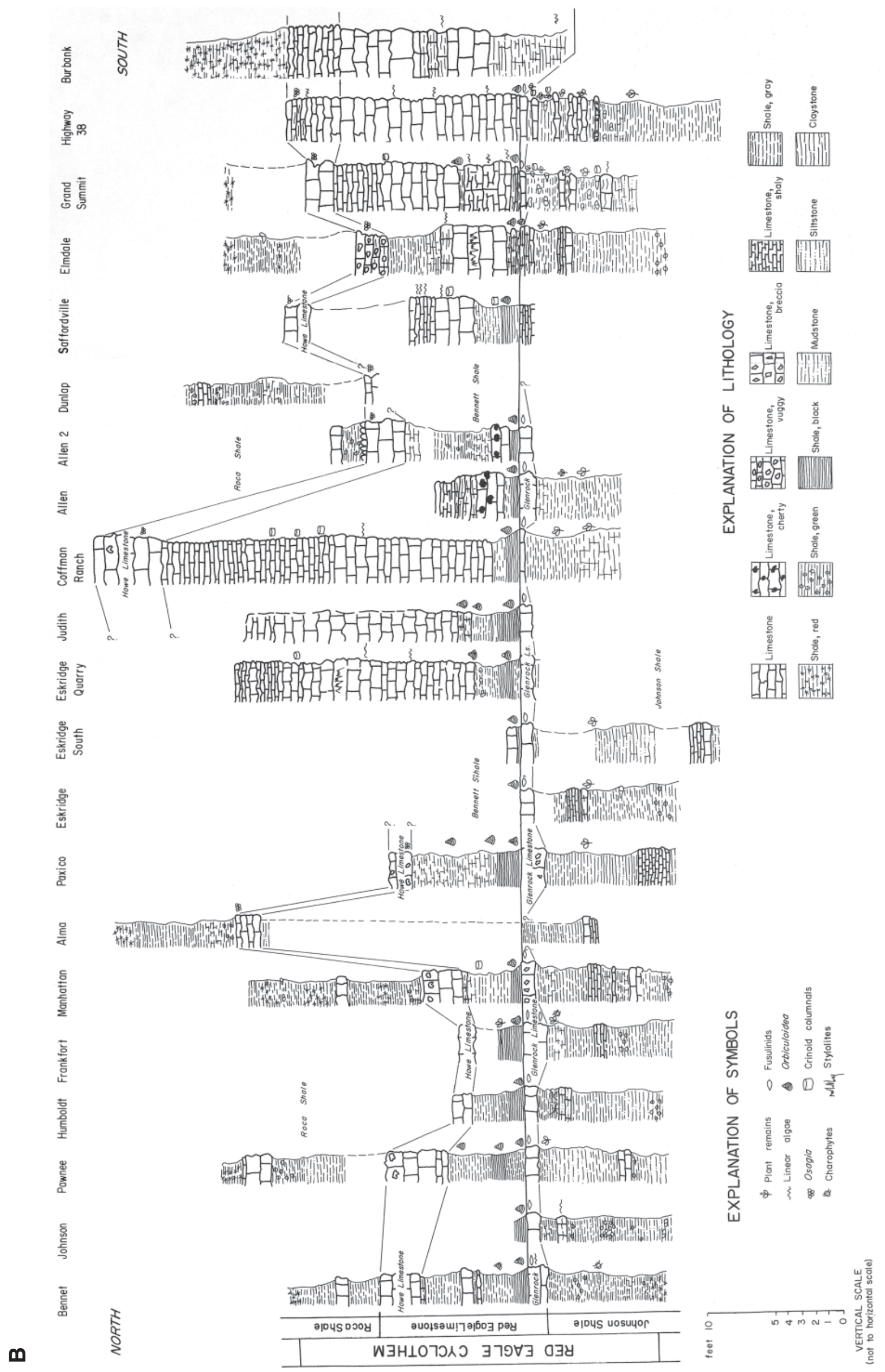

Current Research in Earth Sciences, Bulletin 252, part 2 (http://www.kgs.ku.edu/Current/2006/sawin/index.html) 
different studies conducted on the strata encompassing the Carboniferous-Permian boundary, all who have reported on these strata show that the rocks record relative sea-level fluctuations of different scales.

Early work studied the Red Eagle Limestone within the context of the cyclothem concept and defined the Red Eagle cyclothem to include the Johnson Shale, Red Eagle Limestone, and Roca Shale (e.g., McCrone, 1963). McCrone (1963) related the cyclothem facies to water-depth changes and interpreted water depths ranging from 0 to just over $60 \mathrm{ft}(18 \mathrm{~m})$, although others had interpreted deeper water for some facies (e.g. Elias, 1937). Mudge and Yochelson (1962) called the Red Eagle the typical Council Grove cyclothem. They interpreted the fusulinid facies of the Glenrock Limestone Member to reflect maximum water depth and the Bennett Shale Member and Howe Limestone Member to be regressive deposits, with the Howe being relatively shallow water. Other studies similarly interpreted the Glenrock limestone as the maximum transgressive unit and the Bennett shale as a restricted, nearshore facies (e.g., McCrone, 1963; Clark, 1989). However, as discussed below, other studies have reinterpreted the Bennett shale as the maximum transgressive unit.

More recent studies have evaluated the Red Eagle Limestone within the context of sequence stratigraphy, focusing on significant surfaces and facies in relation to relative sea-level position. Keairns (1995) termed the Red Eagle cyclothem the Red Eagle Sequence. Wardlaw, Boardman, et al. (2004) recognized the same Red Eagle Sequence as a $4^{\text {th }}$-order (0.1-1 m.y.) sequence that occurs within a $3^{\text {rd }}$-order (1-10 m.y.) sequence consisting of the entire Council Grove Group (designated the Council Grove Third Order Sequence). Olszewski and Patzkowsky (2003) also recognize the Red Eagle cyclothem as a $4^{\text {th }}$-order sequence that they termed Composite Sequence IV. All three of these studies place the basal sequence boundary of the Red Eagle Sequence (or Composite Sequence IV) at a subaerial exposure zone (stacked paleosols) within the Johnson Shale and an upper sequence boundary at a subaerial exposure zone (stacked paleosols) within the Roca Shale. These three studies also recognize higher frequency cyclicity ( $5^{\text {th }}$ order; 0.01-0.1 m.y.) within the Red Eagle Sequence (or Composite Sequence IV).

Boardman et al. (1995), Boardman et al. (1998), Boardman (1999), and Wardlaw, Boardman, et al. (2004) used facies and biotic relationships, including water-depth-dependent microfossil biofacies analysis, to interpret depositional history and construct $5^{\text {th }}$-order onshore-to-offshore relative sea-level curves. For the Red Eagle Sequence (or Composite Sequence IV), the marine transgressive surface above the basal sequence boundary (stacked paleosols in the Johnson Shale; Miller, 1994) occurs in the upper part of the Johnson Shale and characteristically is recognized as a thin intraclastic packstone (Boardman, 1999). Transgression continued through deposition of the Glenrock limestone into the Bennett shale. The Glenrock limestone is interpreted as a shallow-water carbonate consisting mostly of sparsely fossiliferous intraclastic packstone to grainstone, with the uppermost portion being a fossil-rich wackestone to packstone characterized by abundant fusulinids (along with coated grains, gastropods, brachiopods, and bivalve debris) and large Thalassinoides-like, or Diplocraterion-type burrows filled with dark-gray to black shale, presumably from the overlying Bennett shale (Miller, 1994; Muehleisen, 1994; Boardman et al., 1998). The contact of the Glenrock limestone with the Bennett shale is sharp (and irregular in places). Boardman et al. (1998) interpreted the contact as a major flooding surface and possible marine hardground, although they do not provide any evidence for a hardground interpretation.

The basal part of the Bennett shale contains the greatest diversity of conodonts (the Streptognathodus biofacies of Boardman et al., 1995) and is interpreted as representing a marine condensed section deposited in an open marine mid-shelf setting. This condensed section at the base of the Bennett shale and a second condensed section, approximately $0.3 \mathrm{~m}$ above in the Bennett shale (also consisting of the Streptognathodus biofacies), represent maximum transgression. In addition to the abundant conodonts, orbiculoid brachiopods, ammonoids, and fish debris are found in the condensed sections. After deposition of the basal condensed section, a minor relative fall in sea level is interpreted for deposition of the limestone unit of the Bennett shale prior to subsequent rise and deposition of the second condensed section (Boardman et al., 1995). At Tuttle Creek the limestone unit of the Bennett shale contains abundant remains of fish teeth and orbiculoid brachiopods (Boardman et al., 1998). According to Boardman et al. (1998), the Bennett changes facies from dark shales in northern and central Kansas to dominantly fossiliferous carbonates in southern Kansas, with the two condensed sections still identifiable as a thin, shaly, glauconitic, fossiliferous wackestone with abundant phosphatized mollusks and abundant Streptognathodus conodonts (lower condensed section) or a thin, highly fossiliferous shale with abundant Streptognathodus conodonts (upper condensed section). For Boardman et al. (1995), Keairns (1995), Boardman et al. (1998), Boardman (1999), and Wardlaw, Boardman, et al. (2004), the two condensed sections in the Bennett shale represent the deepest water conditions (maximum transgression) within the Red Eagle Sequence, and for Wardlaw, Boardman, et al. (2004) the deepest water (maximum transgression) for the entire Council Grove Third Order Sequence. This interpretation differs from earlier work that interpreted the Bennett shale as restricted, nearshore facies (Mudge and Yochelson, 1962; McCrone, 1963; Clark, 1989).

The maximum transgression in the Bennett shale is followed by Howe limestone regressive deposits consisting of foraminiferal grainstones that grade (shallow) upwards to coatedgrain grainstones and stromatolite facies. Shapiro and West (1999) interpret the Howe stromatolites at Tuttle Creek Lake Spillway as being deposited in a shallow subtidal to intertidal open marine setting during an episodic regression, and coeval stromatolites in Lyon County as suggestive of marginal marine to supratidal settings. Regression culminated with deposition of the Roca Shale containing well-developed green to red blocky mudstone; stacked paleosols (Miller, 1994; Rankey and Farr, 1997) form the upper sequence boundary of the Red Eagle Sequence (or Composite Sequence IV). Thin carbonate units interbedded with the paleosols are interpreted as being deposited in marginal marine environments and are shown as minor flooding events on the $5^{\text {th }}$-order sea-level curve for the Roca Shale (Boardman et al., 1995; Boardman et al.,1998; Miller, 1994; Miller et al., 1996; Rankey and Farr, 1997).

In addition to the relative sea-level changes that likely reflect a eustatic signature, at least to some extent, the CarboniferousPermian boundary and associated strata reflect other important broad-scale geologic events and changes. West et al. (1997) noted 
that the boundary reflects a rather abrupt change in the lithologic character of cyclothemic deposition that can be at least partially attributed to climatic change associated with tectonically driven paleogeographic changes (e.g. northward paleolatitudinal shift of the midcontinent) and final assembly of Pangea. Climatically, the Wolfcampian seems to have been a time of major transition from generally wetter conditions in the Virgilian to significantly drier in the Leonardian and Guadalupian. The apparent establishment of a Northern Hemisphere monsoonal circulation by latest Carboniferous to Early Permian, coupled with increasingly more restricted epeiric seaways along the western equatorial Pangea, led to a transition from seasonal humid (Virgilian), to dry (Wolfcampian), to nonseasonal dry (Leonardian) (Tabor and Montanez, 2002).

West et al. (1997) noted that Wolfcampian strata developed during a period of extensive glaciation, similar to conditions during Carboniferous (Desmoinesian) deposition. Ross and Ross (1987) suggested that eustasy even increased during the earlyto-mid Permian. West et al. (1997) postulated that differences in facies composition between Wolfcampian and Desmoinesian cyclic deposits, and an apparent shallowing-upward trend in Permian strata, could also have resulted from continental elevation changes due to thermal uplift (for example, insulating effects of the supercontinent [Anderson, 1982]) and changes in volume of mid-ocean ridges, both of which could have muted the effects of changing glacial ice volume. The migration of Marathon-Ouachita thrusting and foreland flexure to more distal sites in the early Permian, and further assembly of Pangea along the Ural suture zone eventually lead to formation of the supercontinent and increasing influence of these other tectonic processes. This scenario may have support as reflected in the $5^{\text {th }}$-order sea-level curves of Boardman et al. (1995), Boardman et al. (1998), Boardman (1999), and Wardlaw, Boardman, et al. (2004). Following the maximum transgression in the Bennett shale (believed to be the maximum flooding event for the early Permian according to Keairns, 1995), the curves show that magnitudes of sea-level fluctuations are less for cyclic deposits in the rest of the Council Grove and Chase Groups as compared to earlier deposited cyclic strata.

In summary, in addition to being a significant biostratigraphic boundary, the Carboniferous-Permian boundary and enclosing strata also have significance because they reflect important geologic events and changes that occurred on a regional and global scale.

\section{System Boundaries within Lithostratigraphic Units}

The new Carboniferous-Permian system boundary in Kansas falls within a lithostratigraphic unit, the Red Eagle Limestone. The appropriateness of leaving it within the lithostratigraphic unit, or splitting the Red Eagle into two formations at the system boundary, was considered. In accordance with Article 22 of the North American Stratigraphic Code (2005), the boundary will be left within the Red Eagle Limestone.

The North American Stratigraphic Code (North American Commission on Stratigraphic Nomenclature, 2005, Article 22, p. 1,566 ) defines a lithostratigraphic unit as " a defined body of sedimentary, extrusive igneous, metasedimentary, or metavolcanic strata which is distinguished and delimited on the basis of lithic characteristics and stratigraphic position. A lithostratigraphic unit generally conforms to the Law of Superposition and commonly is stratified and tabular in form." Article 22, Remarks (e), "Independence from time concepts" (North American Commission on Stratigraphic Nomenclature, 2005, p. 1,566) also stated "The boundaries of most lithostratigraphic units are time independent, but some may be approximately synchronous. Inferred time-spans, however measured, play no part in differentiating or determining the boundaries of any lithostratigraphic unit." Article 49 of the Code (North American Commission on Stratigraphic Nomenclature, 2005 , p. 1,574) defines a biostratigraphic unit as "...a body of rock defined or characterized by its fossil content." The basic unit in biostratigraphic classification is the biozone, of which there are several kinds. Article 49, Remark (c), "Independence from lithostratigraphic units" stated "Biostratigraphic units are based on criteria that differ fundamentally from those for lithostratigraphic units. Their boundaries may or may not coincide with the boundaries of lithostratigraphic units, but they bear no inherent relation to them."

Thus, it is not inappropriate to have a biostratigraphic boundary within a lithostratigraphic unit, whether it is a member, formation, or group, and therefore, it is unnecessary to change the boundaries of any of these lithostratigraphic units. In the case of the Carboniferous-Permian boundary in Kansas, that biostratigraphic boundary is at the base of the Bennett Shale Member of the Red Eagle Limestone within the Council Grove Group.

\section{Acknowledgments}

Gregory P. Wahlman and Scott Ritter provided careful, constructive reviews of the manuscript, and we are grateful for their time and expertise. Marla Adkins-Heljeson is thanked for editorial assistance, and Jennifer Sims is thanked for graphic arts support.

This paper was completed by current members of the Kansas Geological Survey's Stratigraphic Nomenclature Committee, which was re-established in July 2005, to address stratigraphic issues and establish formally accepted stratigraphic nomenclature for Kansas. The Stratigraphic Nomenclature Committee is the official arbiter of stratigraphic nomenclature and issues in Kansas, subject to review by the State Geologist. 


\section{References}

Anderson, D. L., 1982, Hotspots, polar wander mesozoic convection, and the geoid: Nature, v. 297, p. 391-393.

Baars, D. L., 1990, Permian chronostratigraphy in Kansas: Geology, v. 18, p. 687-690.

Baars, D. L., Ritter, S. M., Maples, C. G., and Ross, C. A., 1994, Redefinition of the Upper Pennsylvanian Virgilian Series in Kansas; in, Revision of Stratigraphic Nomenclature in Kansas, D. L. Baars (compiler): Kansas Geological Survey, Bulletin 230, p. 11-16.

Baars, D. L., Ross, C. A., Ritter, S. M., and Maples, C. G., 1994, Proposed repositioning of the Pennsylvanian-Permian boundary in Kansas; in, Revision of Stratigraphic Nomenclature in Kansas, D. L. Baars (compiler): Kansas Geological Survey, Bulletin 230, p. 5-9.

Barker, G. W., 1983, Palynology of the Admire Group ("Lower Permian") of eastern Kansas: Ph.D. dissertation, Kent State University, $329 \mathrm{p}$.

Barker, G. W., and Eames, L. E., 1988, A standard Permian (Wolfcampian) palynomorph succession from a precisely dated continuous core in Kansas: Amoco Production Company, Technical Report No. 88287, Art. 020, 22 p., 94 pls.

Blakey, R., 2005, Global plate tectonics and paleogeography: Northern Arizona University, web site http://jan.ucc.nau.edu/ rcb7/ (accessed December 2005).

Boardman, D. R., 1999, Virgilian and lowermost Permian sea-level curve and cyclothems; in, Guidebook for XIV-ICCP Field Trip No. 8: Middle and Upper Pennsylvanian (Upper Carboniferous) Cyclothem Succession in Midcontinent Basin, USA, P. H. Heckel (ed.): Held in association with XIV International Congress on the Carboniferous-Permian, Calgary, Canada, sponsored by Kansas Geological Survey and the University of Kansas Energy Research Center; also available as KGS Open-file Report 99-27, p. 103-118.

Boardman, D. R., II, Nestell, M. K., and Knox, L. W., 1995, Depthrelated microfaunal biofacies model for Late Carboniferous and Early Permian cyclothemic sedimentary sequences in midcontinent North America; in, Sequence Stratigraphy of the Midcontinent, N. Hynd (ed.): Tulsa Geological Society, Special Publication, no. 4, p. 93-118.

Boardman, D. R., II, Work, D. M., Mapes, R. H., and Barrick, J. E., 1994, Biostratigraphy of Middle and Late Pennsylvanian (Desmoinesian-Virgilian) ammonoids: Kansas Geological Survey, Bulletin 232, $121 \mathrm{p}$.

Boardman, D. R., II, Nestell, M. K., and Wardlaw, B. R., 1998, Uppermost Carboniferous and lowermost Permian deposition and conodont biostratigraphy of Kansas, USA; in, Permian Stratigraphy, Environments and Resources, v. 2, Y. Jin, B. R. Wardlaw, and Y. Wang (eds.): Palaeoworld, no. 9, p. 19-32.

Branson, C. G., 1964, Cyclicity in Oklahoma Paleozoic rocks; in, Symposium on Cyclic Sedimentation, D. F. Merriam (ed.): Kansas Geological Survey, Bulletin 169, v. 1, p. 57-62.

Chernykh, V. V., and Ritter, S. M., 1994, Preliminary biostratigraphic assessment of conodonts from the proposed Carboniferous-Permian boundary stratotype, Aidaralash Creek, northern Kazakhstan: Permophiles, iss. 25, p. 4-6.

Chernykh, V. V., and Ritter, S. M., 1997, Streptognathodus (Conodonta) succession at the proposed Carboniferous-Permian boundary stratotype section, Aidaralash Creek, northern Kazakhstan: Journal of Paleontology, v. 71, no. 3, p. 459-474.

Chernykh, V. V., Ritter, S. M., and Wardlaw, B. R., 1997, Streptognathodus isolatus new species (Conodonta): Proposed index for the Carboniferous-Permian boundary: Journal of Paleontology, v. 71, no. 1, p. 162-164.

Clark, M. H., 1989, Genetic stratigraphy of the Red Eagle and Roca formations (Lower Permian) of northeast Kansas (abs.): Geological Society of America, Abstracts with Programs, v. 21, no. 1, p. 6.
Condra, G. E., 1927, The stratigraphy of the Pennsylvanian System in Nebraska: Nebraska Geological Survey, Bulletin 1, ser. 2, p. 1-291.

Davydov, V. I., Glenister, B. F., Spinosa, C., Ritter, S. M., Chernykh, V. V., Wardlaw, B. R., and Snyder, W. S., 1995, Proposal of Aidaralash as GSSP for the base of the Permian System: Permophiles, iss. 26, p. $1-9$.

Davydov, V. I., Glenister, B. F., Spinosa, C., Ritter, S. M., Chernykh, V. V., Wardlaw, B. R., and Snyder, W. S., 1998, Proposal of Aidaralash as Global Stratotype Section and Point (GSSP) for base of the Permian System: Episodes, v. 21, no. 1, p. 11-18.

Dickinson, W. R., and Lawton, T. F., 2003, Sequential intercontinental suturing as the ultimate control for Pennsylvanian Ancestral Rocky Mountain deformation: Geology, v. 31, no. 7, p. 609-612.

Dorobek, S. L., 2004, Late Paleozoic deformation of the Permian basin region and other parts of the Marathon-Ouachita foreland: Geological Society of America, Abstracts with Programs, v. 36, no. 5 , p. 509.

Douglass, R. C., 1962, Phylum Protozoa, Class Sarconina - Order Foraminifera, Fusulinidae of the Brownville through Americus interval in Kansas; in, Stratigraphy and Paleontology of the Uppermost Pennsylvanian and Lowermost Permian Rocks in Kansas, M. R. Mudge and E. L. Yochelson (eds.): U.S. Geological Survey, Professional Paper 323, p. 55-64.

Dunn, M. T., 2001, Palynology of the Carboniferous-Permian boundary stratotype, Aidaralash Creek, Kazakhstan: Review of Palaeobotany and Palynology, v. 116, p. 175-194.

Dutton, S.P., and Goldstein, A. G., 1988, Palo Duro, Hardeman, and Dalhart basins; in, Chapter 12, Southern Midcontinent Region, Decade of North America, v. D-2, Sedimentary Cover-North American Craton, U.S., K. S. Johnson et al. (vol. eds.), L. L. Sloss (series ed.): Geological Society of America, p. 341-346.

Elias, M. K., 1937, Depth of deposition of the Big Blue (late Paleozoic) sediments in Kansas: Geological Society of America, Bulletin, v. 48, p. 403-432.

Heald, K. C., 1916, The oil and gas geology of the Foraker quadrangle, Osage County, Oklahoma: U.S. Geological Survey, Bulletin 641, p. 17-47.

Hoy, R. G., and Ridgway, K. D., 2003, Sedimentology and sequence stratigraphy of fan-delta and river-delta depositional systems, Pennsylvanian Minturn Formation, Colorado: American Association of Petroleum Geologists, Bulletin, v. 87, no. 7, p. 1,169-1,191.

Keairns, C., 1995, Sequence stratigraphy of Pennsylvanian-Permian boundary strata from the North American midcontinent: M.S. thesis, Oklahoma State University, $255 \mathrm{p}$.

Keairns, C. E., and Boardman, D. R., II, 2001, Principal reference section of Red Eagle Limestone; in, Pennsylvanian and Permian Geology and Petroleum in the Southern Midcontinent, 1998 Symposium, K. S. Johnson (ed.): Oklahoma Geological Survey, Circular 104, p.115-118.

McCrone, A. W., 1963, Paleoecology and biostratigraphy of the Red Eagle cyclothem (Lower Permian) in Kansas: Kansas Geological Survey, Bulletin 164, 114 p.

McKee, E. D., and Oriel, S. S., 1967, Paleotectonic maps of the Permian System: U.S. Geological Survey, Miscellaneous Geological Investigations Map I-450, $164 \mathrm{p}$.

Miller, K. B., 1994, Tuttle Creek Lake spillway exposure: Cycle patterns and paleosol profiles: Kansas Geological Survey, Open-file Report 94-23, 26 p.

Miller, K. B., McCahon, T. J., and West, R. R., 1996, Lower Permian (Wolfcampian) paleosol-bearing cycles of the U.S. midcontinent: evidence of climatic cyclicity: Journal of Sedimentary Research, v. 66, p. 71-84.

Miller, K. B., and West, R. R., 1998, Identification of sequence boundaries within cyclic strata of the Lower Permian of Kansas, 
U.S.A.: problems and alternatives: Journal of Geology, v. 106, p. 119-132.

Moore, R. C., 1940, Carboniferous-Permian boundary: American Association of Petroleum Geologists, Bulletin, v. 24, no. 2, p. 282336.

1949, Divisions of the Pennsylvanian System in Kansas: Kansas Geological Survey, Bulletin 83, 203 p .

Moore, R. C., and Moss, R. G., 1934, Permian-Pennsylvanian boundary in the northern midcontinent area (abs.): Geological Society of America, Proceedings, 1933, p. 100.

Mudge, M. R., and Yochelson, E. L., 1962, Stratigraphy and paleontology of the uppermost Pennsylvanian and lowermost Permian rocks in Kansas: U.S. Geological Survey, Professional Paper 323, 213 p.

Muehleisen, S. A., 1994, Trace and rare-earth element geochemistry of the Bennett Shale Member (Red Eagle Limestone) and its implications for the depositional environment of this unit at the Tuttle Creek Dam Spillway exposure, eastern Kansas, U.S.A; in, Contributions to the Geology of Rocks Exposed by the "Flood of 93" at the Tuttle Creek Reservoir Spillway near Manhattan, Kansas, R. R. West (compiler): Kansas Geological Survey, Open-file Report 94-36, p. 4.1-4.24.

North American Commission on Stratigraphic Nomenclature, 2005, North American stratigraphic code: American Association of Petroleum Geologists, Bulletin, v. 89, p. 1,547-1,591.

O’Connor, H. G., and Jewett, J. M., 1952, The Red Eagle Formation in Kansas: Kansas Geological Survey, Bulletin 96, part 8, p. 329-362.

Olszewski, T. D., 2000, Testing for a relationship between paleocommunity recurrence and taxonomic turnover using a sequence stratigraphic framework: $\mathrm{PhD}$. dissertation, Pennsylvania State University, $378 \mathrm{p}$.

Olszewski, T. D., and Patzkowsky, M. E., 2003, From cyclothems to sequences: The record of eustasy and climate on an icehouse epeiric platform (Pennsylvanian-Permian, North American midcontinent): Journal of Sedimentary Research, v. 73, no. 1, p. 15-30.

Rankey, E. C., and Farr, M. R., 1997, Preserved pedogenic mineral magnetic signature, pedogeneis, and paleoclimate change: Pennsylvanian Roca Shale (Virgilian, Asselian), central Kansas, U.S.A.: Sedimentary Geology, v. 114, p. 11-32.

Ritter, S. M., 1995, Upper Missourian-Lower Wolfcampian (Upper Kasimovian-Lower Asselian) conodont biostratigraphy of the midcontinent, U.S.A.: Journal of Paleontology, v. 69, no. 6, p. 1,139-1,154.

Ross, C. A., and Ross, J. P. R., 1987, Late Paleozoic depositional sequences; in, Timing and Depositional History of Eustatic Sequences, Figure 4, Permian Cycle Chart, C. A. Ross and D. Haman: Constraints on Seismic Stratigraphy, Cushman Foundation for Foraminiferal Research, Special Publication No. 24, 228 p.

Sanderson, G. A., Verville, G. J., Groves, J. R., and Wahlman, G. P., 2001, Fusulinacean biostratigraphy of the Virgilian Stage (Upper Pennsylvanian) in Kansas: Journal of Paleontology, v. 75, no. 4, p. 883-887.

Scotese, C. R., 2004, A continental drift flipbook: The Journal of Geology, v. 112, p. 729-741.

Scotese, C. R., and McKerrow, W. S., 1990, Revised world maps and introduction; in, Palaeozoic Palaeogeography and Biogeography, W. S. McKerrow and C. R. Scotese (eds.): Geological Society of London, Memoir No. 12, p. 1-21.

Shapiro, R. S., and West, R. R., 1999, Late Paleozoic stromatolites: New insights from the Lower Permian of Kansas: Lethaia, v. 32, no. 2, p. 131-139.
Swallow, G. C., 1858a, Letter to the Academy on the Permian in Kansas: Transactions of the St. Louis Academy of Science, v. 1, p. 111-112. 1858b, On the Permian strata in Kansas Territory: American

Journal of Science, ser. 2, v. 25, no. 74, p. 305.

Sweet, W. C., 1988, The Conodonta-Morphology, taxonomy, paleoecology, and evolutionary history of a long-extinct animal phylum: Oxford Monographs on Geology and Geophysics, Clarendon Press, Oxford and New York, 212 p.

Tabor, N. J., and Montanez, I. P., 2002, Shifts in late Paleozoic atmospheric circulation over western equatorial Pangea: Insights from pedogenic mineral del O-18 compositions: Geology, v. 30, no. 12 , p. $1,127-1,130$.

Thompson, M. L., 1954, American Wolfcampian fusulinids: University of Kansas Paleontologic Contributions, Protozoa, no. 4, art. 5, 225 p.

Utting, J., 1989, Preliminary palynological zonation of surface and subsurface sections of Carboniferous, Permian, and lowest Triassic rocks, Sverdrup basin, Canadian Arctic archipelago: Current Research, Part G, Paper 89-1C, Geological Survey of Canada, Ottawa, Ontario, p. 233-240.

Wahlman, G. P., 1998, Fusulinid biostratigraphy of the new Pennsylvanian-Permian boundary in the southwest and midcontinent U.S.A. (abs.): Geological Society of America, Southcentral Section Meeting, Abstracts with Program, v. 30, no. 3, p. 34. , (in press), Pennsylvanian (Desmoinesian-Virgilian) fusulinid biostratigraphy of the North American midcontinent; in, Midcontinent Volume of Carboniferous of the World, P. H. Heckel (ed.): International Union of Geological Sciences.

Wahlman, G. P., and King, W. E., 2002, Latest Pennsylvanian and earliest Permian fusulinid biostratigraphy, Robledo Mountains and adjacent ranges, south-central New Mexico: New Mexico Bureau of Geology and Mineral Resources, Circular 208, 26 p.

Wang, C., 2000, The base of the Permian System in China defined by Streptognathodus isolatus: Permophiles, no. 36, p. 14-15.

Wardlaw, B. R., and Davydov, V. I., 2000, Preliminary placement of the international Lower Permian working standard to the Glass Mountains, Texas: Permophiles, no. 36, p. 11-14.

Wardlaw, B. R., Davydov, V., and Gradstein, F. M., 2004, The Permian Period; in, A Geologic Time Scale 2004, F. M. Gradstein, J. G. Ogg, and A. G. Smith (eds.): Cambridge University Press, p. 249-270.

Wardlaw, B. R., Boardman, D. R., II, and Nestell, M. K., 2004, Carboniferous-Permian stratigraphy of the midcontinent: Permophiles, no. 44, p. 25-28.

Watney, W. L., Berg, J. A., and Paul, S., 1988, Origin and distribution of the Hutchinson (lower Leonardian) in Kansas; in, Permian Rocks of the Midcontinent, W. A. Morgan and J. A. Babcock (eds.): Midcontinent SEPM, Special Publication No. 1., p. 113-135.

West, R. R. (compiler), 1994, Contributions to the geology of rocks exposed by the "Flood of "93" at the Tuttle Creek Reservoir spillway near Manhattan, Kansas: Kansas Geological Survey, Openfile Report 94-36, 54 p.

West, R. R., Archer, A. W., and Miller, K. B., 1997, The role of climate in stratigraphic patterns exhibited by late Palaeozoic rocks exposed in Kansas: Palaeogeography, Palaeoclimatology, Palaeoecology, v. 128, p. 1-16.

Zeller, D. E., ed., 1968, The stratigraphic succession in Kansas: Kansas Geological Survey, Bulletin 189, 81 p. 